\title{
Effect of feeding on olive oil and thyme on pregnancy and lactation periods
}

\author{
Amany A. Salem \\ Special Food and Nutrition Department, Food Technology Research Institute, Agricultural Research Centre, Ministry of Agriculture, Giza, \\ Egypt
}

Email address:

Amanysalem2013@gmail.com

\section{To cite this article:}

Amany A. Salem. Effect of Feeding on Olive Oil and Thyme on Pregnancy and Lactation Periods. International Journal of Nutrition and Food Sciences. Vol. 4, No. 1, 2015, pp. 19-28. doi: 10.11648/j.ijnfs.20150401.14

\begin{abstract}
This study aimed to evaluate the effect of feeding on virgin olive oil (VOO) and extra virgin olive oil (EVOO) at $50 \%$ and $100 \%$ with or without thyme leaves at $1 \%$ and $2.5 \%$ on pregnancy and lactation periods. Methods: One hundred and twenty adult female rats $(120 \pm 5 \mathrm{~g})$ were randomly divided into 15 groups $(n=8)$ for month before mating. On $19^{\text {th }}$ day of pregnancy, half of pregnant rats were weighted, killed and their fetuses take off with uterus. Another half of pregnant rats were left to evaluate the lactation period. Biochemical assays, bone measurements and fertility hormones were evaluated. Results: Generally, the VOO groups were improved the health status of pregnant and lactating rats more than EVOO groups. The pregnant rats in VOO and thyme leaves powder groups were lower of body weight gain (BWG) without their fetuses than EVOO and thyme leaves powder groups. The mean weight of fetuses in VOO and thyme leaves powder groups were higher than EVOO combined with thyme leaves groups. Also, the feeding on olive oils with thyme leaves had an increase of number of fetuses and bone $\mathrm{Ca}$ and $\mathrm{P}$ contents. The results showed that, in an increasing of number of fetuses caused decrease in bone mineral density (BMD). Pregnant and lactating rats fed on 100\% olive oils had TC, TG, LDL-C, and VLDL-C lower than the rats fed on $50 \%$ olive oils. Also, the rats fed on olive oils and thyme leaves powder had increase in both E2 and progesterone levels before mating and at the end of lactation period compared to control group. Meanwhile, the prolactin hormone levels for rats at the end of lactation period were lower than on $19^{\text {th }}$ day of pregnancy period. Conclusion: Diet which containing with olive oil improved the health status, especially during pregnancy and lactation periods. Consumption of olive oil and olive oil and thyme leaves could be reduce the risk of infertility in females.
\end{abstract}

Keywords: Virgin Olive Oil, Extra Virgin Olive Oil, Thyme Leaves, Pregnant and Lactating Rats, Lipid Profile, Fertility Hormones

\section{Introduction}

Nutrition and reproduction have always been linked in that the reproductive success of an animal depends on its nutritional status. One of the most significant dietary changes that can be made to influence the reproductive system is the addition of fat to the diet. Several studies on reproductive activity of fat-supplemented rats demonstrated an increase in diameter and number of follicles present on the ovary, as well as a shorter period to the first postpartum ovulation [1].

Olive oil is the principal source of lipid within the traditional Mediterranean diet [2]. Olive oil is considered a healthy product because of its constituents, which include oleic acid, palmitic acid and other fatty acids; in addition to traces of squalence and sterols. There is a considerable data demonstrating that the consumption of olive oil is beneficial to cardiovascular health; specifically it has a favorable effect on cholesterol regulation and LDL cholesterol oxidation. It has also been shown to have anti-inflammatory, antithrombotic, antihypertensive and vasodilator effects in both animals and humans [3].Olive oil is an important preventive factor in the pathogenesis of numerous degenerative disease and conditions. Extra virgin olive oil is the best nutritional supplement for pregnant women, due to its ideally balanced nutritionally valuable fats important for intrauterine fetal development as well as optional fatty tissue development during early infancy [4]. Fertility hormones regulate the reproductive cycle and are used to test for various associated conditions including infertility and impotence in men and women, early or delayed puberty as well as non-reproductive disorder. The most common causes 
of female infertility are hormones. These are commonly associated with ovulation, ovarian syndrome and premature ovarian failure, damage to the Fallopian tube or uterus, or problem with cervix [5]. The female reproductive cycles function primarily by the interplay between the luteinizing hormone (LH), follicle stimulating hormone (FSH), progesterone, estradiol, prolactin and testosterone. Hormonal replacement therapy (HRT) is not only possibility to manage certain aspects of adult women's health. Huge women's health initiative study assessing the impact of HRT mainly on cardiovascular health and malignant disease have constructed not only users, but prescribers too. Increase cancer, stroke and coronary heart disease risks associated with long term use of postmenopausal hormone therapy (HT) have rapidly declined the number of women treated with HT either estrogen alone or estrogen plus progesterone [6]. An experimental model showed that bone remodeling was more pronounced in laboratory animals which had been treated with a polyphenols-rich diet [7]. According, [8] reported that the high quality of olive oil reduces low density lipoprotein cholesterol (LDL), peroxidation to significant higher extent than sunflower oil in hypercholesterolemia postmenopausal women. Also, [9] reported that olive oil consumption during adult life was not associated with the risk of breast cancer. While, [10] found that diet supplemented with olive oil modifies iron concentration in serum and liver tissues.

Concerning thyme effect on health status, a little/no information about its effect but [11] reported that thyme causes flood blowing and invokes sexual activities and promotes consciousness and intelligences as well.

The present study designed to study the effect of olive oil and thyme leaves pregnant and lactating rats which evaluated the lipid profile, liver and kidney functions, steroid hormones such as estradiol (E2) and progesterone, and prolactin.

\section{Materials and Methods}

\subsection{Materials}

Virgin olive oil (Olea europaea L.) VOO was purchased from the privet sector (peroxide value $=0.05$ and acidity $<$
0.01) at Sadat City, Egypt. The extra virgin olive oil (EVOO) was obtained from Food Technology Research Institute, Agriculture Research Center, Egypt (peroxide value and acidity were 0.36 and $<0.01$ ). Thyme leaves (Thymus vulgaris) was obtained from Horticulture Research Institute, A.R.C. Egypt; which ground to powder. Casein, vitamins, minerals, cellulose, and choline were purchased from ElGomhoria Company, Cairo, Egypt. Starch and corn oil were purchased from local market, Giza, Egypt. Kits used to determine serum total cholesterol TC, total triglycerides TG, high density lipoprotein cholesterol (HDL), urea, creatinine, ALT, AST, ALP and minerals were punched from GammaTread Company, Cairo Egypt.

\subsection{Biological Experiment}

One hundred and twenty adult Sprague-Dawely female rats $(113-123 \mathrm{~g})$ were purchased from the lab of Animal Department of House in Ophthalmology Research Institute Giza, Egypt. The animals were housed in well aerated cages under hygienic condition $\left(22 \pm 2{ }^{\circ} \mathrm{C}\right.$ and $40-60$ Relative humidity) and fed basal diet [12], for one week as adaptation period. After that the rats were randomly divided into 15 group $(\mathrm{n}=8)$ according to the following experimental diets (Table 1), feeding a month before mating and carried out using one male to 2 females. On $19^{\text {th }}$ day of pregnancy, half of pregnant rats were fasted overnight before weighting and sacrificing. The fetuses were removing with uterus and put it in formalin $(10 \% \mathrm{v} / \mathrm{v})$ to analysis. Another half of pregnant rats were left to birth and lactating their fetuses. At the end of each stage, rats were fasted overnight before sacrificing.

Blood sample were collected from eye plexuses of each rat. It cold in refrigerator for $15 \mathrm{~min}$ and centrifuged at $3000 \mathrm{rpm}$ for $15 \mathrm{~min}$ to separate the serum. Serum was carefully separated and transferred into dry clean Eppendorf tubes and kept frozen at $-18^{\circ} \mathrm{C}$ till analysis. Liver, kidney, heat and also femur were removed by careful dissection and blotted free of adhering blood immediately after sacrificing the rats. The organs and fetuses were washed in saline and dried using filter paper, then weighted and kept in formalin $(10 \% \mathrm{v} / \mathrm{v})$ according to [13].

Table (1). The experimental diets for rats $(g / 100 g)$

\begin{tabular}{|c|c|c|c|c|c|}
\hline Groups & Basal diet without oil & Corn oil & Virgin olive oil & Extra virgin olive oil & Thyme \\
\hline 1 & 90 & 10 & -- & -- & -- \\
\hline 2 & 90 & 5 & 5 & -- & -- \\
\hline 3 & 90 & -- & 10 & -- & -- \\
\hline 4 & 90 & 5 & -- & 5 & -- \\
\hline 5 & 90 & -- & -- & 10 & -- \\
\hline 6 & 89 & 10 & -- & -- & 1 \\
\hline 7 & 87.5 & 10 & -- & -- & 2.5 \\
\hline 8 & 89 & 5 & 5 & -- & 1 \\
\hline 9 & 87.5 & 5 & 5 & -- & 2.5 \\
\hline 10 & 89 & -- & 10 & -- & 1 \\
\hline 11 & 87.5 & -- & 10 & -- & 2.5 \\
\hline 12 & 89 & 5 & -- & 5 & 1 \\
\hline 13 & 87.5 & 5 & -- & 5 & 2.5 \\
\hline 14 & 89 & -- & -- & 10 & 1 \\
\hline
\end{tabular}




\subsection{Methods}

Biochemical assays: Serum total triglycerides (TG), total cholesterol (TC) and high density lipoprotein cholesterol (HDL) were determined according to [14], [15] and [16], respectively. Meanwhile, low and very low density lipoprotein cholesterol (LDL and VLDL) were calculated using the equation reported by [17]. The risk factor (TC/HDL-C ratio) was calculated using the equation reported by [18]. Serum urea and creatinine as kidney function were determined by the methods of [19] and [20], respectively. Serum AST and ALT were assayed according to [21]. Serum alkaline phosphatase (ALP) was determined according to [22].

Bone analysis: Bone $\mathrm{Ca}$ and $\mathrm{P}$ were determined according to the methods outlined in [23]. Bon length of each femur was measured using a varnein caliper according to the method of [24]. Bone mineral density (BMD) was determined using Dual energy x-ray absorptiometry (Norland XR -46) as described by [25]. Estradiol (E2), progesterone and prolactin hormones were determined according to [26], [27] and [28], respectively.

Minerals determination of fetuses: Fetuses body minerals were determined using the following procedure: immediately after removal and placed in beakers then, desiccated to the body weight at $100^{\circ} \mathrm{C}$ in a convection oven. Fetus $\mathrm{Ca}, \mathrm{Fe}, \mathrm{Zn}$ and $\mathrm{P}$ of dry weight (DW) determined according to [29].

Statistical analysis: Statistical analyses were carried out by SPSS19 program. Data were expressed as means \pm SEM and the Statistical analysis was performed using one-way analysis of variance followed by Duncan's tests as according to [30].

\section{Results}

\subsection{Effect of Feeding Olive Oil and Thyme Leaves Powder on BWG, Number and Weight of Fetuses}

Weight gain of pregnant and lactating rats, number and weight of fetuses were recorded in Table (2). A month later of feeding the female rats weight ranged from $163.3-183.3 \mathrm{~g}$ and mating to induce pregnancy. The results reported, the pregnant rats fed on $50 \%$ VOO had higher BWG1 than that fed on $100 \%$ VOO. While, the results showed high significant increases in $100 \%$ VOO group compared to $50 \%$ VOO group in weight of fetuses. Concerning, EVOO groups (both 50 and $100 \%$ ) resulted in non-significant differences for mother's BWG1 and weight of fetuses. The pregnant rats fed on $2.5 \%$ thyme leaves powder only with basal diet had higher weight of fetuses and lower mother's BWG1 than that group fed on $1 \%$ of thyme leaves powder. The VOO groups and thyme leaves were higher than EVOO groups for number and weight of fetuses. The pregnant rats were left to delivery and lactating their babies for 4 weeks, and weighted before sacrificing. The data collected in this stage showed the BWG of female rats from initial weight to end of lactation period. Generally, all groups had lower than control groups of BWG except the group fed on $100 \%$ of VOO only. Also, the groups fed on olive oil (50 and 100\%) and thyme leaves powder $(2.5 \%)$ had lower than groups fed on olive oil (50 and 100\%) and thyme leaves powder $(1 \%)$. It is worth mentioning that the presence of olive oil with/without thyme resulted in an increase in the number of fetuses by about 1.33 to 2.00 fold as that of control.

\subsection{Effect of Feeding Olive Oil and Thyme Leaves Powder on Organs Weight}

Table (3) showed the effect of feeding olive oil combined with thyme on the organs of the pregnant and lactating female rats. Generally, the organs weight (liver, heart and kidney) of lactating rats were higher than pregnant rats, but the spleen weight was a low weight of lactating rats compared to pregnant rats. The rats in control group were the lowest value of heart weight $(0.39 \mathrm{~g})$, and the highest values of liver and spleen weight (9.17 and $1.50 \mathrm{~g}$, respectively) for pregnant rats. The additional of $2.5 \%$ of thyme leaves increased in heart, kidney and spleen weight for pregnant and lactating rats compared to additional $1 \%$ of thyme leaves. The same table (3) resulted in VOO groups had lower than EVOO groups for liver, heart and spleen weight on $19^{\text {th }}$ day of pregnancy. While, VOO groups had higher than EVOO groups at the end of lactation period. The feeding on VOO combined with thyme leaves showed decrease when compared to feeding on EVOO combined with thyme leaves for liver weight. There were a high significantly differences between groups for liver, kidney and spleen weight.

\subsection{Effect of Feeding Olive Oil and Thyme Leaves Powder on Some Minerals Contents of Fetuses}

The results in table (4) showed the $\mathrm{Ca}, \mathrm{P}, \mathrm{Fe}$ and $\mathrm{Zn}$ of fetuses as resulted in feeding pregnant rats on olive oils with/without thyme leaves powder. Generally, fetuses in control group were lowest levels of $\mathrm{Ca}$ and $\mathrm{P}$, but the highest levels of $\mathrm{Fe}$ and $\mathrm{Zn}$. The rats in 100\% groups (both VOO and EVOO) were higher than $50 \%$ for $\mathrm{Ca}$ and $\mathrm{P}$ contents. Also, the additional $(2.5 \%)$ of thyme leaves powder caused a slight increase in both $\mathrm{Ca}$ and $\mathrm{P}$ compared to (1\%) level. The rats fed on VOO and thyme leaves groups were higher Fe and $\mathrm{Zn}$ contents than rats in EVOO combined with thyme leaves groups.

\subsection{Effect of Feeding Olive Oil and Thyme Leaves Powder on Bone Ash, Ca and P Contents}

The results in table (5) showed that, the effect of feeding on olive oils combined with/without thyme leaves on bone analysis. The rats in control group had the lowest levels of bone ash, $\mathrm{Ca}$ and $\mathrm{P}$ contents (47.94 vs $39.84 \%$ ), (18.65 vs $15.54 \mathrm{mg} / 100 \mathrm{~g})$ and $(9.14 \mathrm{vs} 8.20 \mathrm{mg} / 100 \mathrm{~g})$ for pregnant vs lactating rats, respectively. Generally, the lactating rats were lower than pregnant rats for bone ash, $\mathrm{Ca}$ and $\mathrm{P}$ contents. The VOO groups were higher bone $\mathrm{Ca}$ and $\mathrm{P}$ contents than EVOO groups. Also, 100\% olive oils groups were higher 
than $50 \%$ for $\mathrm{Ca}$ and $\mathrm{P}$ contents. The decrease in ash, $\mathrm{Ca}$ and $\mathrm{P}$ in lactating rats' bone may be due to the transportation of these mineral to the fetus during pregnancy and to milk during lactation period, too.

\subsection{Effect of Feeding Olive Oil and Thyme Leaves Powder on Bone Measurements}

Bone mineral density (BMD), bone minerals concentration (BMC), bone length (L) and bone weight (W) were measured for the pregnant and lactating rats fed olive oils and thyme leaves powder as shown as in (Table 6). Generally, BMD values for lactating rats were lower than pregnant rats. The results showed that, a slight differences between VOO groups and EVOO groups for bone mineral density of femurs (BMD). Data in Table (2) and Table (6) showed a negative relationship between no. of fetuses and BMD. The pregnant and lactating rats showed low values of BMD with a high no. of fetuses. The VOO groups had higher levels of BMD than EVOO groups. Almost there were not differences between groups in bone length. The VOO groups had higher bone weight than EVOO groups. Also, 100\% of olive oils groups had higher bone weight than $50 \%$ groups. From the above data, it could be concluded the olive oil with/without thyme leaves powder affected on bone BMD, BMC, length and weight of both pregnant and lactating rats.

\subsection{Effect of Feeding Olive Oil and Thyme Leaves Powder on Lipid Profile}

The results in table (7) showed that, the effect of VOO and EVOO combined with thyme leaves on lipid profile in serum pregnant and lactating rats. The results indicated that, lipid profile was lower in pregnant rats fed on VOO than the other rats fed on EVOO. The $2.5 \%$ thyme leaves powder caused decrease in lipid profile compared to $1 \%$. Moreover, feeding rats EVOO and thyme leaves powder had lower levels of lipid profile than feeding on VOO with thyme leaves for pregnant rats.

Concerning the lactating rats, which feeding 11 weeks (before mating, pregnancy period and lactating period) on VOO groups had decrease of TC more than lactating rats fed on EVOO groups, and increase in TG. The addition of $(100 \%)$ olive oil diets caused decrease in lipid profile more than $50 \%$ groups.

The same table (7) indicated that, the pregnant rats which feeding on olive oil diets for 7 weeks (before mating, pregnancy period) had high levels of TC/HDL-C ratio compared to control group. While, lactating rats which feeding (11 weeks) were low levels of TC/HDL-C ratio compared to control group, expect group fed on EVOO (50\%) had the highest level (4.77) of TC/HDL-C ratio.

\subsection{Effect of Feeding Olive Oil and Thyme Leaves Powder on Liver and Kidney Function}

Table (8) showed the effect of feeding olive oil and thyme leaves powder in different levels on the kidney and liver function of both pregnant and lactating female rats. Generally, the liver and kidney functions of lactating rats were higher than pregnant rats. The results indicated that, $100 \%$ of olive oil diets caused decrease in liver and kidney function compared to $50 \%$ of olive oil diets. Moreover, in additional $2.5 \%$ of thyme leaves powder caused decrease in kidney functions and ALP, and increase in AST and ALT for pregnant and lactating rats. Also, feeding on olive oil and thyme leaves diets (2.5\%) had lower liver and kidney functions than rats fed on olive oil and thyme leaves diets $(1 \%)$.

\subsection{Effect of Feeding Olive Oil and Thyme Leaves Powder on Fertility Hormones}

The Fertility hormones for female rats during experimental stages are shown in Table (9). Generally, the rats fed on $100 \%$ of olive oil diets groups were higher in E2 and progesterone levels than rats fed on $50 \%$ of olive oil diets before mating and at the end of lactation period. Also, the rats fed on olive oils combined with thyme leaves had increase in E2 and progesterone levels before mating and at the end of lactation period compared to control group. Meanwhile, the prolactin hormone levels for rats at the end of lactation period were lower than on $19^{\text {th }}$ day of pregnancy period. The rats feeding VOO and thyme leaves powder diets were lower that feeding EVOO and thyme leaves powder diets for prolactin level.

\section{Discussion}

In this study, the author attempted to clarify the potential of the olive oil and thyme on pregnant and lactating health. The results indicated that, the BWG was decrease compared to control at the end of experimental period. These results of body weight gain are in the line with [31] who found the BWG after second month was lower than BWG in the first month.

These results are in the line with [10] who found that, the olive oil diet reduced the serum Fe compared to control group (corn oil diet).

An experimental model showed that bone remodeling was more pronounced in laboratory animals which had been treated with a paly phenol diet [7]. A possible influence of olive oil on bone mass inteance and osteoporosis prevention, its results showed that women on a Mediterranean diet rich in olive oil had better bone density levels than those on a standard diet [32].

Concerning monounsaturated fatty acids, a positive association between BMD and monounsaturated fat, derived mostly from olive oil, has been reported in a sample of Greek men and women [33]. The investigators discussed the influence that vitamin E, abundant in olive oil, exerts on prostaglandin levels and therefore on bone formation and resorption. Furthermore, a dose-response protective effect of oleuropain, an olive oil polyphenol, has been found on bone mass in an experimental in vivo model of bone loss in rats [34]. Accordingly, [35] concluded that olive polyphenols, particularly hydroxytyrosol, prevented bone loss in ovariectomized 
mice, and suggested olive polyphenols may provide insights into the development of tools useful in preventing and treating osteoporosis.

The results of lipid profile are in the line with [36] who found that organic olive oil was most efficacious in addressing levels of TC, HDL, LDL, and AI. For all the parameters (except TG and VLDL), organic olive oil not only ameliorated but also prevented changes. In this respect, [37] reported that the intake of phenol rich virgin olive oil decrease total cholesterol TC, LDL and TG levels and substantially increased HDL concentrations. Controlled studies carried out with phenol-rich olive oils also have shown reductions of blood lipids and also of aortic lesions in hypercholesterolemic rabbits when fed with diets devoid of cholesterol [38].

The results of liver functions are in the line with [36] who reported maximum reduction of these measures as compared to the control $(+)$ group was found in the thyme oil and organic olive oil and in fact, the AST, ALT and ALP. Also, the olive oil and thyme leaves had a high significantly differences compared to negative control.

Our results are not in the line with [39] who found the estradiol (E2) for group which administered olive oil showed a non-significant difference when compared to the control group. The groups administered soybean oil and olive oil showed a non-significant decrease in progesterone levels relative to the control group.

Progesterone and estradiol are among the most important sex hormones for implantation of the blastocyst and pregnancy maintenance [40]. In pregnant females, with a normal menstrual cycle, the progesterone level remains relatively constant throughout the follicular phase of the menstrual cycle and then increases rapidly following ovulation, while the estradiol secretion follows a cyclic biphasic pattern, with highest concentration found immediately prior to ovulation [41]. Based on the results obtained in this study, it shows that the two kind of olive oil (virgin olive oil and extra virgin olive oil) which contained omega-3 and omega-6 PUFAs and MUFAs have strong capability of enhancing hormonal functions by stimulating hypothalamus-pituitary ovarian axis and subsequently the fertility in females.

Estradiol is mainly synthesized by the granulose and theca cells of the ovaries. Serum estradiol level is principally used to monitor the induction of ovulation and differential diagnosis of amenorrhea. From the results of this study serum progesterone level was non-significantly decrease in soy oil and olive oil treated groups when comparison with the control group. Furthermore, serum estradiol level showed that, olive oil group showed an insignificant difference relative to the control group, indicating that the hypothalamus-pituitary gonadal axis was not affected [40].

Prolactin is a hormone that plays a role in fertility by inhibiting follicle stimulating hormone and gonadotropin releasing hormone $(\mathrm{GnRH})$, the hormones that trigger ovulation and allow eggs to develop and mature. In the present study, prolactin level in the olive oil treated group was significantly increased relative to the control group. High prolactin levels tend to suppress the ovulatory cycle by inhibiting the secretion of both follicle stimulating hormone and gonadotropin-releasing hormones ( $\mathrm{Gn} \mathrm{RH})$ [42] which are necessary for ovulation. Based on the results obtained in this study, it shows that the two kind of olive oil (virgin olive oil and extra virgin olive oil) which contained omega-3 and omega-6 PUFAs and MUFAs have strong capability of enhancing hormonal functions by stimulating hypothalamuspituitary ovarian axis and subsequently the fertility in females.

\section{Conclusion}

From the obtained data it could be concluded that, diets containing olive oil with/without thyme leaves powder improved lipid profile, liver and kidney functions especially for the pregnant and lactating, provided that doses do not greatly exceed the amounts used in food. Olive oils and thyme leaves have strong capability of enhancing hormonal functions by subsequently the fertility of females. Hence, consumption of these oils could be reduce risk of infertility in females. Traditionally, thyme is reported to the effect the menstrual cycle and, therefore, large amounts could not be ingested.

Table (2). Effect of feeding olive oil and thyme Powder diets on $B W G^{*}$, Number of fetus and weight lactating rats ( $g$ )

\begin{tabular}{|c|c|c|c|c|c|c|c|c|c|c|}
\hline \multirow[b]{2}{*}{ Groups } & \multirow[b]{2}{*}{ Initial } & \multirow[b]{2}{*}{$\begin{array}{l}\text { Before } \\
\text { mating }\end{array}$} & \multicolumn{3}{|c|}{ Mother on $19^{\text {th }}$ day of pregnancy } & \multicolumn{3}{|c|}{$\begin{array}{l}\text { Fetuses on } 19^{\text {th }} \text { day of } \\
\text { pregnancy }\end{array}$} & \multicolumn{2}{|c|}{$\begin{array}{l}\text { End the lactation } \\
\text { period }\end{array}$} \\
\hline & & & $\begin{array}{l}\text { Mother } \\
\text { body } \\
\text { weight }\end{array}$ & BWG1 & $\begin{array}{l}\text { BWG1 without } \\
\text { weight of } \\
\text { fetuses }\end{array}$ & $\begin{array}{l}\text { No. } \\
\text { of } \\
\text { fetus }\end{array}$ & $\begin{array}{l}\text { Weight } \\
\text { of } \\
\text { fetuses }\end{array}$ & $\begin{array}{l}\text { Means } \\
\text { weight } \\
\text { of fetus }\end{array}$ & $\begin{array}{l}\text { Body } \\
\text { weight }\end{array}$ & BWG2 \\
\hline 1 control & $118.33^{\mathrm{a}}$ & $175.00^{\mathrm{a}}$ & $251.60^{\text {ef }}$ & $76.67^{\mathrm{abc}}$ & 59.10 & $6^{\mathrm{d}}$ & $17.50^{\mathrm{j}}$ & 2.92 & $214.00^{\mathrm{b}}$ & $95.67^{\mathrm{b}}$ \\
\hline $250 \%$ Virgin Olive Oil (VOO) & $116.67^{\mathrm{a}}$ & $177.00^{\mathrm{a}}$ & $275.67^{\mathrm{ab}}$ & $98.67^{\mathrm{a}}$ & 67.30 & $9^{c}$ & $31.37^{\mathrm{h}}$ & 3.49 & $163.30^{\text {cd }}$ & $48.33^{\text {cde }}$ \\
\hline 3 100\% Virgin Olive Oil (VOO) & $121.00^{\mathrm{a}}$ & $172.00^{\mathrm{a}}$ & $267.00^{\mathrm{cd}}$ & $95.00^{\mathrm{a}}$ & 47.87 & $8^{\mathrm{c}}$ & $47.13^{\mathrm{c}}$ & 5.89 & $259.67^{\mathrm{a}}$ & $138.67^{\mathrm{a}}$ \\
\hline $\begin{array}{l}4 \quad 50 \% \text { Extra Virgin Olive Oil } \\
(\text { EVOO) }\end{array}$ & $123.33^{\mathrm{a}}$ & $169.33^{\mathrm{a}}$ & $250.67^{\mathrm{f}}$ & $81.33^{\mathrm{abc}}$ & 40.23 & $8^{c}$ & $41.1^{\mathrm{e}}$ & 5.14 & $205.00^{\mathrm{b}}$ & $81.67^{\mathrm{bcd}}$ \\
\hline $\begin{array}{l}5100 \% \text { Extra Virgin Olive Oil } \\
\text { (EVOO) }\end{array}$ & $122.67^{\mathrm{a}}$ & $166.00^{\mathrm{a}}$ & $249.00^{\mathrm{fg}}$ & $83.00^{\mathrm{abc}}$ & 41.80 & $9^{c}$ & $41.2^{\mathrm{e}}$ & 4.58 & $191.67^{\mathrm{bc}}$ & $69.00^{\text {bcde }}$ \\
\hline $61 \%$ Thyme & $122.33^{\mathrm{a}}$ & $174.33^{\mathrm{a}}$ & $254.33^{\text {ef }}$ & $80.00^{\mathrm{abc}}$ & 36.43 & $10^{\mathrm{b}}$ & $43.57^{\mathrm{de}}$ & 4.36 & $165.00^{\mathrm{cd}}$ & $42.67^{\mathrm{de}}$ \\
\hline 7 2.5\% Thyme & $119.00^{\mathrm{a}}$ & $171.70^{\mathrm{a}}$ & $242.00^{\text {gh }}$ & $70.33^{\mathrm{bc}}$ & 25.83 & $9^{c}$ & $44.5^{\mathrm{d}}$ & 4.94 & $146.67^{\mathrm{d}}$ & $27.67^{\mathrm{e}}$ \\
\hline $850 \%$ VOO $+1 \%$ Thyme & $121.66^{\mathrm{a}}$ & $179.00^{\mathrm{a}}$ & $270.00^{\mathrm{bc}}$ & $91.00^{\mathrm{ab}}$ & 34.07 & $12^{\mathrm{a}}$ & $56.93^{\mathrm{ab}}$ & 4.74 & $188.67^{\mathrm{bc}}$ & $67.00^{\mathrm{bcd}}$ \\
\hline $950 \%$ VOO+2.5\% Thyme & $120.00^{\mathrm{a}}$ & $174.30^{\mathrm{a}}$ & $239.00^{\mathrm{h}}$ & $64.67^{\mathrm{c}}$ & 43.47 & $9^{c}$ & $21.2^{\mathrm{i}}$ & 2.36 & $161.00^{\text {cd }}$ & $41.00^{\mathrm{de}}$ \\
\hline $10100 \%$ VOO $+1 \%$ Thyme & $119.00^{\mathrm{a}}$ & $177.70^{\mathrm{a}}$ & $259.00^{\mathrm{de}}$ & $82.00^{\mathrm{abc}}$ & 24.43 & $12^{\mathrm{a}}$ & $57.57^{\mathrm{a}}$ & 4.80 & $179.33^{\mathrm{bcd}}$ & $62.00^{\mathrm{bcd}}$ \\
\hline
\end{tabular}




\begin{tabular}{|c|c|c|c|c|c|c|c|c|c|c|}
\hline \multirow[b]{2}{*}{ Groups } & \multirow[b]{2}{*}{ Initial } & \multirow[b]{2}{*}{$\begin{array}{l}\text { Before } \\
\text { mating }\end{array}$} & \multicolumn{3}{|c|}{ Mother on $19^{\text {th }}$ day of pregnancy } & \multicolumn{3}{|c|}{$\begin{array}{l}\text { Fetuses on } 19^{\text {th }} \text { day of } \\
\text { pregnancy }\end{array}$} & \multicolumn{2}{|c|}{$\begin{array}{l}\text { End the lactation } \\
\text { period }\end{array}$} \\
\hline & & & $\begin{array}{l}\text { Mother } \\
\text { body } \\
\text { weight }\end{array}$ & BWG1 & $\begin{array}{l}\text { BWG1 without } \\
\text { weight of } \\
\text { fetuses }\end{array}$ & $\begin{array}{l}\text { No. } \\
\text { of } \\
\text { fetus }\end{array}$ & $\begin{array}{l}\text { Weight } \\
\text { of } \\
\text { fetuses }\end{array}$ & $\begin{array}{l}\text { Means } \\
\text { weight } \\
\text { of fetus }\end{array}$ & $\begin{array}{l}\text { Body } \\
\text { weight }\end{array}$ & BWG2 \\
\hline 11 100\% VOO+2.5\%Thyme & $120.00^{\mathrm{a}}$ & $183.33^{\mathrm{a}}$ & $265.33^{\text {cd }}$ & $82.00^{\mathrm{abc}}$ & 27.03 & $11^{\mathrm{ab}}$ & $54.97^{\mathrm{b}}$ & 5.00 & $178.33^{\text {bcd }}$ & $58.33^{\text {bcd }}$ \\
\hline $1250 \%$ (EVOO) + 1\%Thyme & $119.33^{\mathrm{a}}$ & $175.00^{\mathrm{a}}$ & $251.67^{\mathrm{ef}}$ & $76.67^{\mathrm{abc}}$ & 40.07 & $8^{c}$ & $36.60^{g f}$ & 4.58 & $152.67^{\mathrm{cd}}$ & $33.33^{\mathrm{e}}$ \\
\hline $1350 \%$ (EVOO) + 2.5\% Thyme & $120.00^{\mathrm{a}}$ & $163.33^{\mathrm{a}}$ & $260.00^{\mathrm{de}}$ & $96.67^{\mathrm{a}}$ & 61.40 & $8^{c}$ & $35.27^{\mathrm{g}}$ & 4.41 & $180.00^{\text {bd }}$ & $63.33^{\text {bcde }}$ \\
\hline $14100 \%$ (EVOO) + $1 \%$ Thyme & $118.33^{\mathrm{a}}$ & $173.70^{\mathrm{a}}$ & $240.00^{\mathrm{h}}$ & $66.33^{\mathrm{c}}$ & 28.20 & $9^{c}$ & $38.13^{\mathrm{f}}$ & 4.24 & $209.67^{\mathrm{b}}$ & $91.33^{\mathrm{bc}}$ \\
\hline $15100 \%$ (EVOO) $+2.5 \%$ Thyme & $120.00^{\mathrm{a}}$ & $181.00^{\mathrm{a}}$ & $279.00^{\mathrm{a}}$ & $98.00^{\mathrm{a}}$ & 63.47 & $11^{\mathrm{ab}}$ & $34.53^{\mathrm{g}}$ & 3.14 & $155.33^{\mathrm{cd}}$ & $35.30^{\mathrm{de}}$ \\
\hline
\end{tabular}

$* \mathrm{BWG} 1=$ (body weight gain on $19^{\text {th }}$ days of pregnancy - weight rats before mating). $\quad$ BWG; without weight of fetuses $=(\mathrm{BWG1}-$ mean weight of fetuses $)$. BWG2 = (body weight gain in the end experimental - initial). $\quad * *$ Each value in a column followed by the same letter are not significantly different at $\mathrm{p} \leq 0.05$.

Table (3). Effect of feeding on olive oil and thyme diets on organs weight of pregnant and lactating rats $(\mathrm{g})$

\begin{tabular}{|c|c|c|c|c|c|c|c|c|}
\hline \multirow{2}{*}{ Groups } & \multicolumn{2}{|l|}{ Heart } & \multicolumn{2}{|l|}{ Liver } & \multicolumn{2}{|l|}{ Kidney } & \multicolumn{2}{|l|}{ Spleen } \\
\hline & Pregnant & Lactating & Pregnant & Lactating & Pregnant & Lactating & Pregnant & Lactating \\
\hline 1 control & $0.39^{\mathrm{e}}$ & $0.96^{\mathrm{a}}$ & $9.17^{\mathrm{a}}$ & $7.53^{\mathrm{ef}}$ & $1.27^{\mathrm{ab}}$ & $1.34^{\mathrm{de}}$ & $1.50^{\mathrm{a}}$ & $0.76^{\mathrm{ab}}$ \\
\hline $250 \%$ Virgin Olive Oil & $0.53^{\mathrm{cd}}$ & $0.80^{\mathrm{bc}}$ & $7.23^{f}$ & $6.17^{\mathrm{gh}}$ & $1.03^{\mathrm{b}}$ & $1.83^{\mathrm{a}}$ & $0.84^{\mathrm{bc}}$ & $0.30^{\mathrm{f}}$ \\
\hline $450 \%$ Extra Virgin Olive Oil & $0.50^{\mathrm{d}}$ & $0.86^{\mathrm{ab}}$ & $6.2^{\mathrm{h}}$ & $8.6^{\mathrm{a}}$ & $1.07^{\mathrm{ab}}$ & $1.97^{\mathrm{a}}$ & $0.61^{\text {def }}$ & $0.80^{\mathrm{a}}$ \\
\hline $5 \quad 100 \%$ Extra Virgin Olive Oil & $0.49^{d}$ & $0.63^{\mathrm{def}}$ & $7.9^{\mathrm{de}}$ & $8.17^{\mathrm{bc}}$ & $1.13^{\mathrm{ab}}$ & $1.36^{\mathrm{de}}$ & $0.80^{\mathrm{bc}}$ & $0.75^{\mathrm{abc}}$ \\
\hline $6 \quad 1 \%$ Thyme & $0.61^{\mathrm{bc}}$ & $0.56^{\mathrm{ef}}$ & $8.63^{b}$ & $7.50^{\text {ef }}$ & $1.03^{\mathrm{b}}$ & $1.33^{\mathrm{de}}$ & $0.60^{\text {defg }}$ & $0.65^{\mathrm{cd}}$ \\
\hline $850 \%$ VOO+1\%Thyme & $0.62^{b}$ & $0.60^{\mathrm{ef}}$ & $8.61^{\mathrm{b}}$ & $7.23^{f}$ & $1.30^{\mathrm{ab}}$ & $1.23^{\mathrm{e}}$ & $0.70^{\mathrm{d}}$ & $0.58^{\mathrm{de}}$ \\
\hline $950 \%$ VOO $+2.5 \%$ Thyme & $0.61^{\mathrm{bc}}$ & $0.53^{\mathrm{fg}}$ & $8.60^{\mathrm{b}}$ & $8.17^{\mathrm{bc}}$ & $1.30^{\mathrm{ab}}$ & $1.16^{\mathrm{e}}$ & $0.81^{\mathrm{bc}}$ & $0.63^{d}$ \\
\hline $10100 \%$ VOO+1\%Thyme & $0.61^{\mathrm{bc}}$ & $0.67^{\text {def }}$ & $7.33^{f}$ & $8.43^{\mathrm{ab}}$ & $1.17^{\mathrm{ab}}$ & $1.53^{\mathrm{cd}}$ & $0.62^{\mathrm{de}}$ & $0.79^{\mathrm{a}}$ \\
\hline $11100 \%$ VOO $+2.5 \%$ Thyme & $0.51^{\mathrm{d}}$ & $0.80^{\mathrm{bc}}$ & $7.40^{\mathrm{f}}$ & $8.70^{\mathrm{a}}$ & $1.02^{\mathrm{c}}$ & $1.76^{\mathrm{ab}}$ & $0.59^{\text {efg }}$ & $0.78^{\mathrm{a}}$ \\
\hline $1250 \%$ EVOO + 1\% Thyme & $0.61^{\mathrm{bc}}$ & $0.86^{\mathrm{ab}}$ & $8.33^{\mathrm{bc}}$ & $7.43^{\text {ef }}$ & $1.05^{\mathrm{b}}$ & $1.37^{\text {de }}$ & $0.87^{\mathrm{b}}$ & $0.85^{\mathrm{a}}$ \\
\hline $1350 \%$ EVOO + 2.5\% Thyme & $0.51^{\mathrm{d}}$ & $0.53^{\mathrm{fg}}$ & $8.34^{\mathrm{bc}}$ & $6.00^{\mathrm{h}}$ & $1.13^{\mathrm{ab}}$ & $1.40^{\mathrm{de}}$ & $0.60^{\text {defg }}$ & $0.83^{\mathrm{a}}$ \\
\hline $14100 \%$ EVOO + 1\% Thyme & $0.51^{\mathrm{d}}$ & $0.53^{\mathrm{fg}}$ & $8.06^{\mathrm{cd}}$ & $8.06^{\mathrm{cd}}$ & $1.35^{\mathrm{a}}$ & $1.36^{\mathrm{de}}$ & $0.51^{\mathrm{fg}}$ & $0.85^{\mathrm{a}}$ \\
\hline $15100 \%$ EVOO $+2.5 \%$ Thyme & $0.71^{\mathrm{a}}$ & $0.43^{\mathrm{g}}$ & $7.57^{\text {ef }}$ & $7.53^{\text {ef }}$ & $1.20^{\mathrm{ab}}$ & $1.71^{\mathrm{ab}}$ & $0.50^{\mathrm{g}}$ & $0.67^{\text {bcd }}$ \\
\hline
\end{tabular}

*Each value in a column followed by the same letter are not significantly different at $\mathrm{p} \leq 0.05$.

Table (4). Effect of feeding on olive oil and thyme diets on some minerals (mg/100g) of fetuses

\begin{tabular}{|c|c|c|c|c|c|}
\hline \multicolumn{2}{|c|}{ Groups } & \multirow{2}{*}{$\begin{array}{l}\mathbf{C a} \\
13.60^{\mathrm{h}}\end{array}$} & \multirow{2}{*}{$\begin{array}{l}\mathbf{P} \\
6.40^{\mathrm{h}}\end{array}$} & \multirow{2}{*}{$\begin{array}{l}\mathbf{F e} \\
8.64^{\mathrm{a}}\end{array}$} & \multirow{2}{*}{$\begin{array}{l}\mathbf{Z n} \\
3.18^{\mathrm{a}}\end{array}$} \\
\hline & control & & & & \\
\hline 2 & $50 \%$ Virgin Olive Oil & $13.70^{\mathrm{g}}$ & $6.25^{\mathrm{ij}}$ & $6.82^{\mathrm{bc}}$ & $2.69^{\mathrm{bc}}$ \\
\hline 3 & $100 \%$ Virgin Olive Oil & $13.90^{\mathrm{f}}$ & $6.70^{\mathrm{f}}$ & $5.79^{\operatorname{defg}}$ & $2.39^{\text {cdef }}$ \\
\hline 4 & $50 \%$ Extra Virgin Olive Oil & $13.4^{\mathrm{i}}$ & $6.00^{\mathrm{k}}$ & $6.85^{\mathrm{bc}}$ & $2.64^{\mathrm{bcd}}$ \\
\hline 5 & $100 \%$ Extra Virgin Olive Oil & $13.98^{\mathrm{e}}$ & $6.88^{\mathrm{e}}$ & $6.29^{\text {cde }}$ & $2.14^{\mathrm{f}}$ \\
\hline 6 & $1 \%$ Thyme & $13.94^{\mathrm{ef}}$ & $6.49^{\mathrm{g}}$ & $5.38^{\mathrm{g}}$ & $2.29^{\mathrm{def}}$ \\
\hline 7 & $2.5 \%$ Thyme & $13.98^{\mathrm{e}}$ & $7.01^{\mathrm{d}}$ & $7.5^{\mathrm{b}}$ & $2.68^{\mathrm{bc}}$ \\
\hline 8 & $50 \%$ vOO $+1 \%$ Thyme & $13.55^{\mathrm{h}}$ & $6.21^{\mathrm{j}}$ & $5.71^{\mathrm{efg}}$ & $2.45^{\text {bcdef }}$ \\
\hline 9 & $50 \%$ VOO $+2.5 \%$ Thyme & $13.73^{\mathrm{h}}$ & $6.35^{\mathrm{h}}$ & $6.24^{\text {cdef }}$ & $2.51^{\text {bcdef }}$ \\
\hline & $100 \%$ VOO+1\%Thyme & $13.60^{\mathrm{h}}$ & $6.32^{\mathrm{hi}}$ & $5.70^{\mathrm{efg}}$ & $2.25^{\mathrm{ef}}$ \\
\hline & $100 \%$ VOO+2.5\% Thyme & $14.12^{\mathrm{c}}$ & $7.11^{\mathrm{c}}$ & $5.45^{\mathrm{fg}}$ & $2.31^{\text {def }}$ \\
\hline & $50 \%$ EVOO $+1 \%$ Thyme & $13.90^{\mathrm{f}}$ & $6.49^{\mathrm{g}}$ & $6.68^{\mathrm{c}}$ & $2.55^{\text {bcde }}$ \\
\hline & $50 \%$ EVOO $+2.5 \%$ Thyme & $14.05^{\mathrm{d}}$ & $7.00^{\mathrm{d}}$ & $8.48^{\mathrm{a}}$ & $3.24^{\mathrm{a}}$ \\
\hline & $100 \%$ EVOO + $1 \%$ Thyme & $14.33^{\mathrm{b}}$ & $7.21^{\mathrm{b}}$ & $6.58^{\mathrm{cd}}$ & $2.82^{\mathrm{b}}$ \\
\hline & $100 \%$ EVOO + $2.5 \%$ Thyme & $14.56^{\mathrm{a}}$ & $7.35^{\mathrm{a}}$ & $6.44^{\text {cde }}$ & $2.55^{\text {bcde }}$ \\
\hline
\end{tabular}

*Each value in a column followed by the same letter are not significantly different at $(\mathrm{p} \leq 0.05)$.

Table (5). Effect of feeding on olive oil and thyme diets on bone ash, Ca and P contents for pregnant and lactating rats

\begin{tabular}{|c|c|c|c|c|c|c|c|}
\hline \multirow{2}{*}{\multicolumn{2}{|c|}{ Groups }} & \multicolumn{2}{|l|}{ Ash (\%) } & \multicolumn{2}{|l|}{$\mathrm{Ca}(\mathrm{mg} / \mathbf{1 0 0 g})$} & \multicolumn{2}{|l|}{$P(\mathrm{mg} / \mathbf{1 0 0 g})$} \\
\hline & & Pregnant rats & Lactating rats & Pregnant rats & Lactating rats & Pregnant rats & Lactating rats \\
\hline 1 & control & $47.49^{g}$ & $39.84^{\mathrm{k}}$ & $18.65^{\mathrm{f}}$ & $15.54^{\mathrm{j}}$ & $9.90^{\mathrm{h}}$ & $8.20^{\mathrm{j}}$ \\
\hline 2 & $50 \%$ Virgin Olive Oil & $55.63^{\mathrm{b}}$ & $45.18^{\mathrm{i}}$ & $20.77^{\mathrm{c}}$ & $19.96^{\mathrm{b}}$ & $9.06 \mathrm{i}$ & $9.33^{\mathrm{e}}$ \\
\hline 3 & $100 \%$ Virgin Olive Oil & $52.03^{\mathrm{de}}$ & $46.52^{\mathrm{h}}$ & $18.71^{\mathrm{f}}$ & $16.23^{\mathrm{i}}$ & $10.20^{\mathrm{fg}}$ & $9.53^{\mathrm{d}}$ \\
\hline 4 & $50 \%$ Extra Virgin Olive Oil & $50.11^{\mathrm{f}}$ & $47.57^{\mathrm{g}}$ & $19.59^{\mathrm{e}}$ & $19.27^{\mathrm{d}}$ & $10.85^{\mathrm{d}}$ & $8.22^{\mathrm{i}}$ \\
\hline 5 & $100 \%$ Extra Virgin Olive Oil & $50.39^{\mathrm{f}}$ & $49.65^{\mathrm{e}}$ & $20.59^{\text {cd }}$ & $18.57^{\mathrm{e}}$ & $11.67^{\mathrm{b}}$ & $9.05^{\mathrm{fg}}$ \\
\hline 6 & $1 \%$ Thyme & $53.40^{\mathrm{c}}$ & $52.52^{\mathrm{a}}$ & $19.55^{\mathrm{e}}$ & $16.39^{\mathrm{i}}$ & $10.63^{\mathrm{e}}$ & $8.54^{\mathrm{i}}$ \\
\hline 7 & $2.5 \%$ Thyme & $53.49^{\mathrm{c}}$ & $46.56^{\mathrm{h}}$ & $20.29^{d}$ & $17.44^{\mathrm{h}}$ & $11.67^{\mathrm{b}}$ & $8.55^{\mathrm{i}}$ \\
\hline 8 & $50 \%$ VOO $+1 \%$ Thyme & $53.64^{\mathrm{c}}$ & $50.62^{\mathrm{c}}$ & $21.59^{\mathrm{ab}}$ & $20.68^{\mathrm{a}}$ & $11.58^{\mathrm{b}}$ & $10.30^{\mathrm{b}}$ \\
\hline 9 & $50 \%$ VOO $+2.5 \%$ Thyme & $51.50^{\mathrm{e}}$ & $48.39^{\mathrm{f}}$ & $20.84^{\mathrm{c}}$ & $18.25^{\mathrm{f}}$ & $10.92^{\mathrm{d}}$ & $9.82^{\mathrm{c}}$ \\
\hline
\end{tabular}




\begin{tabular}{llllllll}
\hline \multirow{2}{*}{ Groups } & \multicolumn{2}{l}{ Ash (\%) } & Ca $(\mathbf{m g} / \mathbf{1 0 0 g})$ & & P $(\mathbf{m g} / \mathbf{1 0 0 g})$ \\
\cline { 2 - 7 } & Pregnant rats & Lactating rats & Pregnant rats & Lactating rats & Pregnant rats & Lactating rats \\
\hline 10 & $100 \%$ VOO+1\%Thyme & $52.18^{\mathrm{d}}$ & $50.48^{\mathrm{cd}}$ & $21.86^{\mathrm{a}}$ & $18.34^{\mathrm{f}}$ & $11.28^{\mathrm{c}}$ & $9.05^{\mathrm{fg}}$ \\
11 & $100 \%$ VOO+2.5\%Thyme & $53.69^{\mathrm{c}}$ & $50.82^{\mathrm{c}}$ & $21.49^{\mathrm{b}}$ & $19.64^{\mathrm{c}}$ & $10.07^{\mathrm{gh}}$ & $10.83^{\mathrm{a}}$ \\
12 & $50 \%$ EVOO + $1 \%$ Thyme & $56.30^{\mathrm{a}}$ & $48.88^{\mathrm{f}}$ & $18.84^{\mathrm{f}}$ & $16.31^{\mathrm{i}}$ & $9.14^{\mathrm{i}}$ & $8.94^{\mathrm{g}}$ \\
13 & $50 \%$ EVOO + 2.5\%Thyme & $55.48^{\mathrm{b}}$ & $50.04^{\mathrm{de}}$ & $20.64^{\mathrm{c}}$ & $17.82^{\mathrm{g}}$ & $10.34^{\mathrm{f}}$ & $9.60^{\mathrm{d}}$ \\
14 & $100 \%$ EVOO + $1 \%$ Thyme & $49.78^{\mathrm{f}}$ & $43.46^{\mathrm{i}}$ & $19.27^{\mathrm{e}}$ & $17.87^{\mathrm{g}}$ & $10.54^{\mathrm{e}}$ & $9.10^{\mathrm{f}}$ \\
15 & $100 \%$ EVOO + $2.5 \%$ Thyme & $55.43^{\mathrm{b}}$ & $51.86^{\mathrm{b}}$ & $18.25^{\mathrm{g}}$ & $16.26^{\mathrm{i}}$ & $12.07^{\mathrm{a}}$ & $8.72^{\mathrm{h}}$ \\
\hline
\end{tabular}

*Each value in a column followed by the same letter are not significantly different at $(\mathrm{p} \leq 0.05)$.

Table (6). Effect of feeding on olive oil and thyme diets on bone measurements (X-ray and length and weight) for pregnant and lactating female rats

\begin{tabular}{|c|c|c|c|c|c|c|c|c|c|}
\hline \multirow{2}{*}{\multicolumn{2}{|c|}{ Groups }} & \multicolumn{4}{|c|}{ Pregnant rats } & \multicolumn{4}{|c|}{ Lactating rats } \\
\hline & & \multirow{2}{*}{$\begin{array}{c}\text { BMD }^{1} \\
0.0962\end{array}$} & \multirow{2}{*}{$\frac{\text { BMC }^{2}}{0.0936}$} & \multirow{2}{*}{$\begin{array}{l}\mathbf{L} \\
3.143^{\mathrm{c}}\end{array}$} & \multirow{2}{*}{$\begin{array}{l}\mathbf{W} \\
0.241^{\mathrm{d}}\end{array}$} & \multirow{2}{*}{$\begin{array}{l}\text { BMD }^{1} \\
0.1116\end{array}$} & \multirow{2}{*}{$\begin{array}{l}\text { BMC }^{2} \\
0.1636\end{array}$} & \multirow{2}{*}{$\begin{array}{l}\mathbf{L} \\
3.263^{\mathrm{abc}}\end{array}$} & \multirow{2}{*}{$\begin{array}{l}\mathbf{W} \\
0.241^{\mathrm{c}}\end{array}$} \\
\hline 1 & control & & & & & & & & \\
\hline 2 & $50 \%$ Virgin Olive Oil & 0.1118 & 0.1477 & $3.100^{\text {cd }}$ & $0.469^{\mathrm{a}}$ & 0.1018 & 0.1762 & $2.897^{\mathrm{d}}$ & $0.252^{\mathrm{c}}$ \\
\hline 3 & $100 \%$ Virgin Olive Oil & 0.1213 & 0.1815 & $3.493^{\mathrm{a}}$ & $0.350^{\mathrm{c}}$ & 0.1039 & 0.1854 & $3.153^{\mathrm{bcd}}$ & $0.529^{\mathrm{a}}$ \\
\hline 4 & $50 \%$ Extra Virgin Olive Oil & 0.1190 & 0.1760 & $2.963^{\mathrm{efg}}$ & $0.251^{\mathrm{d}}$ & 0.1126 & 0.1049 & $3.067^{\mathrm{bcd}}$ & $0.463^{\mathrm{ab}}$ \\
\hline 5 & $100 \%$ Extra Virgin Olive Oil & 0.1089 & 0.1047 & $3.067^{\text {cde }}$ & $0.470^{\mathrm{a}}$ & 0.1148 & 0.1790 & $3.280^{\mathrm{ab}}$ & $0.529^{\mathrm{ab}}$ \\
\hline 6 & $1 \%$ Thyme & 0.1013 & 0.1358 & $3.110^{\text {cd }}$ & $0.249^{\mathrm{d}}$ & 0.1058 & 0.1954 & $3.323^{\mathrm{ab}}$ & $0.459^{\mathrm{ab}}$ \\
\hline 7 & $2.5 \%$ Thyme & 0.1211 & 0.0763 & $3.010^{\operatorname{defg}}$ & $0.237^{\mathrm{d}}$ & 0.1138 & 0.2574 & $3.133^{\mathrm{bcd}}$ & $0.544^{\mathrm{a}}$ \\
\hline 8 & $50 \%$ VOO $+1 \%$ Thyme & 0.1047 & 0.1205 & $3.367^{\mathrm{b}}$ & $0.457^{\mathrm{a}}$ & 0.1075 & 0.1819 & $3.153^{\mathrm{bcd}}$ & $0.529^{\mathrm{a}}$ \\
\hline 9 & $50 \%$ VOO $+2.5 \%$ Thyme & 0.1296 & 0.2107 & $2.917^{\mathrm{g}}$ & $0.249^{\mathrm{d}}$ & 0.1115 & 0.1785 & $3.460^{\mathrm{a}}$ & $0.334^{\mathrm{bc}}$ \\
\hline 10 & $100 \%$ VOO+ $1 \%$ Thyme & 0.1097 & 0.1038 & $3.163^{\mathrm{c}}$ & $0.254^{\mathrm{d}}$ & 0.1054 & 0.1161 & $3.220^{\mathrm{abc}}$ & $0.462^{\mathrm{ab}}$ \\
\hline 11 & $100 \%$ VOO $+2.5 \%$ Thyme & 0.1132 & 0.1327 & $3.011^{\text {defg }}$ & $0.238^{\mathrm{d}}$ & 0.0958 & 0.1882 & $3.237^{\mathrm{abc}}$ & $0.450^{\mathrm{a}}$ \\
\hline 12 & $50 \%$ EVOO $+1 \%$ Thyme & 0.1063 & 0.0790 & $3.153^{\mathrm{c}}$ & $0.245^{\mathrm{d}}$ & 0.1055 & 0.1357 & $2.920^{\mathrm{d}}$ & $0.247^{\mathrm{c}}$ \\
\hline 13 & $50 \%$ EVOO + $2.5 \%$ Thyme & 0.1085 & 0.1397 & $3.160^{\mathrm{c}}$ & $0.259^{\mathrm{a}}$ & 0.1122 & 0.2003 & $3.090^{\mathrm{bcd}}$ & $0.334^{\mathrm{ab}}$ \\
\hline 14 & $100 \%$ EVOO + $1 \%$ Thyme & 0.1143 & 0.1418 & $2.953 \mathrm{fg}$ & $0.236^{\mathrm{d}}$ & 0.1174 & 0.2025 & $2.997^{\mathrm{cd}}$ & $0.461^{\mathrm{ab}}$ \\
\hline 15 & $100 \%$ EVOO + 2.5\% Thyme & 0.1012 & 0.1728 & $3.057^{\text {def }}$ & $0.439^{b}$ & 0.0985 & 0.2113 & $2.933^{\mathrm{d}}$ & $0.460^{\mathrm{ab}}$ \\
\hline
\end{tabular}

* Each value in a column followed by the same letter are not significantly different at $\mathrm{p} \leq 0.05$.

BMD: bone mineral density of the femurs $\left(\mathrm{g} / \mathrm{cm}^{3}\right.$ bone vol.) BMC: bone mineral concentrate $(\mathrm{g}) \quad \mathrm{L}$ : bone length (cm) W: bone weight ( $\mathrm{g}$ )

Table (7). Effect of feeding on olive oil and thyme diets on lipid profile ( $\mathrm{mg} / \mathrm{dl})$ of pregnant and lactating rats

\begin{tabular}{|c|c|c|c|c|c|c|c|c|c|c|c|c|}
\hline \multirow[b]{2}{*}{ Groups } & \multicolumn{6}{|c|}{ Pregnant rats } & \multicolumn{6}{|c|}{ Lactating rats } \\
\hline & T. C. & T.G. & HDL-C & LDL-C & $\begin{array}{l}\text { VLDL- } \\
\text { C }\end{array}$ & $\begin{array}{l}\text { Risk } \\
\text { factor }\end{array}$ & T. C. & T.G. & HDL-C & LDL-C & $\begin{array}{l}\text { VLDL- } \\
\text { C }\end{array}$ & $\begin{array}{l}\text { Risk } \\
\text { factor }\end{array}$ \\
\hline 1 control & $145.00^{\mathrm{b}}$ & $127.33^{\mathrm{h}}$ & $53.66^{\mathrm{a}}$ & $65.87^{\mathrm{a}}$ & $25.47^{\mathrm{h}}$ & $2.70^{g}$ & $173.33^{\mathrm{g}}$ & 120.47 & $38.60^{\mathrm{cd}}$ & $110.64^{\mathrm{hi}}$ & $24.09^{\mathrm{bc}}$ & $4.49^{\mathrm{b}}$ \\
\hline $\begin{array}{l}250 \% \text { Virgin Olive Oil } \\
\text { (VOO) }\end{array}$ & $161.00^{\mathrm{h}}$ & $108.00^{\mathrm{de}}$ & $36.67^{\mathrm{e}}$ & $102.73^{\mathrm{j}}$ & $21.60^{\mathrm{de}}$ & $4.39^{\mathrm{a}}$ & $157.57^{\mathrm{c}}$ & $141.20^{\mathrm{c}}$ & $44.33^{\mathrm{b}}$ & $84.99^{\mathrm{a}}$ & $28.24^{\mathrm{c}}$ & $3.55^{\mathrm{h}}$ \\
\hline $\begin{array}{l}3100 \% \text { Virgin Olive Oil } \\
\text { (VOO) }\end{array}$ & $154.33^{\mathrm{fg}}$ & $108.23^{\mathrm{de}}$ & $37.33^{\mathrm{e}}$ & $95.40^{\mathrm{fghi}}$ & $21.60^{\mathrm{de}}$ & $4.13^{\mathrm{bc}}$ & $147.33^{\mathrm{a}}$ & $85.23^{\mathrm{ab}}$ & $41.00^{\mathrm{c}}$ & $89.29^{\mathrm{ab}}$ & $17.05^{\mathrm{ab}}$ & $3.59^{\mathrm{h}}$ \\
\hline $\begin{array}{l}450 \% \text { Extra Virgin Olive } \\
\text { Oil (EVOO) }\end{array}$ & $158.33^{\mathrm{gh}}$ & $131.33^{\mathrm{i}}$ & $42.32^{\text {cd }}$ & $89.73^{\text {bcde }}$ & $26.27^{\mathrm{i}}$ & $3.74^{\mathrm{d}}$ & $187.67^{\mathrm{i}}$ & $132.00^{\mathrm{c}}$ & $39.33^{\mathrm{cd}}$ & $121.93^{\mathrm{j}}$ & $26.40^{\mathrm{c}}$ & $4.77^{\mathrm{a}}$ \\
\hline $\begin{array}{l}5100 \% \text { Extra Virgin Olive } \\
\text { Oil (EVOO) }\end{array}$ & $148.67^{\text {bcd }}$ & $97.33^{\mathrm{b}}$ & $43.33^{\mathrm{cd}}$ & $85.87^{\mathrm{bcd}}$ & $19.47^{\mathrm{b}}$ & $3.43^{\mathrm{e}}$ & $179.67^{\mathrm{h}}$ & $124.67^{\mathrm{c}}$ & $50.63^{\mathrm{a}}$ & $104.10^{\mathrm{fgh}}$ & $24.93^{\mathrm{c}}$ & $3.55^{\mathrm{h}}$ \\
\hline $61 \%$ Thyme & $166.67^{\mathrm{i}}$ & $110.00^{\mathrm{e}}$ & $45.00^{\mathrm{c}}$ & $99.67^{\mathrm{ij}}$ & $22.00^{\mathrm{e}}$ & $3.70^{\mathrm{d}}$ & $156.68^{\mathrm{bc}}$ & $126.53^{\mathrm{c}}$ & $38.93^{\mathrm{cd}}$ & $92.43^{\text {abcd }}$ & $25.31^{\mathrm{c}}$ & $4.02^{\mathrm{d}}$ \\
\hline $72.5 \%$ Thyme & $155.00^{\mathrm{fg}}$ & $103.33^{\mathrm{c}}$ & $36.67^{\mathrm{e}}$ & $97.68^{\text {ghij }}$ & $20.67^{\mathrm{c}}$ & $4.23^{\mathrm{ab}}$ & $164.66^{\mathrm{e}}$ & $113.00^{\mathrm{bc}}$ & $41.00^{\mathrm{c}}$ & $101.07^{\mathrm{efg}}$ & $22.60^{\mathrm{bc}}$ & $4.02^{\mathrm{d}}$ \\
\hline $850 \%$ VOO $+1 \%$ Thyme & $168.00^{\mathrm{i}}$ & $92.67^{\mathrm{a}}$ & $51.33^{\mathrm{ab}}$ & $98.13^{\mathrm{hij}}$ & $18.53^{\mathrm{a}}$ & $3.27^{\mathrm{e}}$ & $154.32^{\mathrm{b}}$ & $72.50^{\mathrm{a}}$ & $39.67^{\mathrm{cd}}$ & $100.17^{\text {def }}$ & $14.50^{\mathrm{a}}$ & $3.89^{\mathrm{f}}$ \\
\hline $950 \%$ VOO+2.5\% Thyme & $159.67^{\mathrm{h}}$ & $134.67^{\mathrm{i}}$ & $42.66^{\text {cd }}$ & $90.07^{\text {cdef }}$ & $26.93^{\mathrm{i}}$ & $3.74^{\mathrm{d}}$ & $156.33^{\mathrm{bc}}$ & $113.27^{\mathrm{bc}}$ & $39.57^{\text {cd }}$ & $94.11^{\text {bcde }}$ & $22.65^{\mathrm{bc}}$ & $3.95^{\mathrm{e}}$ \\
\hline $10100 \%$ VOO+1\%Thyme & $149.67^{\text {cde }}$ & $96.66^{\mathrm{b}}$ & $37.33^{\mathrm{e}}$ & $93.00^{\text {efgh }}$ & $19.33^{\mathrm{b}}$ & $4.01^{\mathrm{c}}$ & $174.00^{\mathrm{g}}$ & $117.60^{\mathrm{bc}}$ & $48.58^{\mathrm{a}}$ & $101.91^{\mathrm{efg}}$ & $23.52^{\mathrm{bc}}$ & $3.58^{\mathrm{h}}$ \\
\hline $11100 \%$ & $162.33^{\mathrm{h}}$ & $104.67^{\mathrm{cd}}$ & $50.30^{\mathrm{ab}}$ & $91.07^{\text {def }}$ & $20.93^{\text {cd }}$ & $3.23^{\mathrm{e}}$ & $187.00^{\mathrm{i}}$ & $129.33^{\mathrm{c}}$ & $44.66^{\mathrm{b}}$ & $116.47^{\mathrm{ij}}$ & $25.87^{\mathrm{c}}$ & $4.19^{c}$ \\
\hline
\end{tabular}




\begin{tabular}{|c|c|c|c|c|c|c|c|c|c|c|c|c|}
\hline \multirow[b]{2}{*}{ Groups } & \multicolumn{6}{|c|}{ Pregnant rats } & \multicolumn{6}{|c|}{ Lactating rats } \\
\hline & T. C. & T.G. & HDL-C & LDL-C & $\begin{array}{l}\text { VLDL- } \\
\mathrm{C}\end{array}$ & $\begin{array}{l}\text { Risk } \\
\text { factor }\end{array}$ & T. C. & T.G. & HDL-C & LDL-C & $\begin{array}{l}\text { VLDL- } \\
\mathrm{C}\end{array}$ & $\begin{array}{l}\text { Risk } \\
\text { factor }\end{array}$ \\
\hline \multicolumn{13}{|l|}{ VOO $+2.5 \%$ Thyme } \\
\hline $\begin{array}{l}1250 \%(\text { EVOO })+ \\
1 \% \text { Thyme }\end{array}$ & $138.67^{\mathrm{a}}$ & $110.33^{\mathrm{e}}$ & $48.65^{\mathrm{b}}$ & $67.93^{\mathrm{a}}$ & $22.07^{\mathrm{e}}$ & $2.85^{\mathrm{f}}$ & $168.01^{\mathrm{f}}$ & $107.93^{\mathrm{abc}}$ & $44.67^{b}$ & $101.75^{\mathrm{efg}}$ & $21.59^{\mathrm{abc}}$ & $3.76^{\mathrm{g}}$ \\
\hline $\begin{array}{l}1350 \%(\text { EVOO })+ \\
2.5 \% \text { Thyme }\end{array}$ & $152.67^{\mathrm{def}}$ & $116.66^{\mathrm{fg}}$ & $37.00^{\mathrm{e}}$ & $92.33^{\mathrm{efg}}$ & $23.33^{\mathrm{fg}}$ & $4.13^{\mathrm{bc}}$ & $170.00^{\mathrm{f}}$ & $115.20^{\mathrm{bc}}$ & $38.00^{\mathrm{d}}$ & $108.96^{\text {ghi }}$ & $23.04^{\mathrm{bc}}$ & $4.47^{\mathrm{b}}$ \\
\hline $\begin{array}{l}14100 \%(\text { EVOO) + } \\
1 \% \text { Thyme }\end{array}$ & $147.67^{\mathrm{bc}}$ & $115.00^{\mathrm{f}}$ & $40.33^{\mathrm{de}}$ & $84.33^{\mathrm{b}}$ & $23.00^{\mathrm{f}}$ & $3.66^{\mathrm{d}}$ & $161.33^{\mathrm{d}}$ & $110.80^{\mathrm{bc}}$ & $40.10^{\mathrm{c}}$ & $99.07^{\text {cdef }}$ & $22.16^{\mathrm{bc}}$ & $4.02^{\mathrm{d}}$ \\
\hline $\begin{array}{l}15100 \%(\text { EVOO })+ \\
2.5 \% \text { Thyme }\end{array}$ & $153.33^{\text {ef }}$ & $119.67^{\mathrm{g}}$ & $44.68^{\mathrm{c}}$ & $84.73^{\mathrm{bc}}$ & $23.93^{\mathrm{g}}$ & $3.43^{\mathrm{e}}$ & $167.33^{\text {ef }}$ & $128.57^{\mathrm{c}}$ & $50.00^{\mathrm{a}}$ & $91.62^{\mathrm{abc}}$ & $25.71^{\mathrm{c}}$ & $3.35^{\mathrm{c}^{\mathrm{c}}}$ \\
\hline
\end{tabular}

* Each value in a column followed by the same letter are not significantly different at $(\mathrm{p} \leq 0.05)$.

Table (8). Effect of feeding on olive oil and thyme diets on liver and kidney functions of pregnant and lactating rats

\begin{tabular}{|c|c|c|c|c|c|c|c|c|c|c|}
\hline \multirow[b]{2}{*}{ Groups } & \multicolumn{5}{|c|}{ Pregnant rats } & \multicolumn{5}{|c|}{ Lactating rats } \\
\hline & $\begin{array}{l}\begin{array}{l}\text { Urea } \\
(\mathrm{mg} / \mathrm{dl})\end{array} \\
\end{array}$ & $\begin{array}{l}\begin{array}{l}\text { Creat. } \\
(\mathrm{mg} / \mathrm{dl})\end{array} \\
\end{array}$ & $\begin{array}{l}\mathbf{A S T} \\
(\mathrm{U} / \mathrm{L})\end{array}$ & $\begin{array}{l}\text { ALT } \\
(\mathrm{U} / \mathrm{L})\end{array}$ & $\begin{array}{l}\text { ALP } \\
(\mathrm{U} / \mathrm{L})\end{array}$ & $\begin{array}{l}\text { Urea } \\
(\mathrm{mg} / \mathrm{dl})\end{array}$ & $\begin{array}{l}\text { Creat. } \\
(\mathrm{mg} / \mathrm{dl})\end{array}$ & $\begin{array}{l}\text { AST } \\
(\mathrm{U} / \mathrm{L})\end{array}$ & $\begin{array}{l}\text { ALT } \\
(\mathrm{U} / \mathrm{L})\end{array}$ & $\begin{array}{l}\mathbf{A L P} \\
(\mathrm{U} / \mathrm{L})\end{array}$ \\
\hline 1 control & $20.50^{\text {cd }}$ & $0.74^{\mathrm{c}}$ & $16.00^{\mathrm{g}}$ & $15.73^{\text {gh }}$ & $96.00^{\mathrm{j}}$ & $25.57^{\mathrm{ef}}$ & $0.83^{\mathrm{c}}$ & $16.60^{\mathrm{f}}$ & $14.87^{\mathrm{g}}$ & $146.67^{\mathrm{bcd}}$ \\
\hline $250 \%$ Virgin Olive Oil (VOO) & $22.57^{\mathrm{ef}}$ & $0.82^{\mathrm{de}}$ & $19.57^{\mathrm{bc}}$ & $21.57^{\mathrm{a}}$ & $110.00^{\mathrm{g}}$ & $25.00^{\mathrm{e}}$ & $0.84^{\mathrm{cd}}$ & $27.50^{\mathrm{a}}$ & $25.60^{\mathrm{a}}$ & $154.66^{\mathrm{bcd}}$ \\
\hline 3 100\% Virgin Olive Oil (VOO) & $17.00^{\mathrm{a}}$ & $0.53^{\mathrm{a}}$ & $18.33^{\text {cde }}$ & $18.67^{\mathrm{cd}}$ & $111.67^{\mathrm{ef}}$ & $19.90^{\mathrm{b}}$ & $0.71^{\mathrm{b}}$ & $21.63^{\mathrm{cd}}$ & $22.53^{\mathrm{c}}$ & $160.00^{\mathrm{abc}}$ \\
\hline $450 \%$ Extra Virgin Olive Oil (EVOO) & $18.93^{\mathrm{b}}$ & $0.64^{\mathrm{b}}$ & $20.77^{\mathrm{ab}}$ & $19.00^{\mathrm{bc}}$ & $114.63^{\mathrm{d}}$ & $30.37^{\mathrm{j}}$ & $0.90^{\mathrm{de}}$ & $24.97^{\mathrm{b}}$ & $24.33^{\mathrm{b}}$ & $132.77^{\text {cdef }}$ \\
\hline $\begin{array}{l}5100 \% \text { Extra Virgin Olive Oil } \\
\text { (EVOO) }\end{array}$ & $25.57^{\mathrm{g}}$ & $0.89^{f}$ & $20.50^{\mathrm{ab}}$ & $21.57^{\mathrm{a}}$ & $98.00^{\mathrm{i}}$ & $21.63^{\mathrm{c}}$ & $0.72^{\mathrm{b}}$ & $18.53^{\mathrm{e}}$ & $16.63^{\mathrm{f}}$ & $159.00^{\mathrm{abc}}$ \\
\hline $61 \%$ Thyme & $22.43^{\mathrm{ef}}$ & $0.71^{\mathrm{c}}$ & $13.00^{\mathrm{h}}$ & $13.58^{\mathrm{i}}$ & $129.63^{\mathrm{a}}$ & $28.36^{\mathrm{hi}}$ & $0.91^{\mathrm{e}}$ & $14.57^{\mathrm{g}}$ & $13.50^{\mathrm{h}}$ & $185.33^{\mathrm{a}}$ \\
\hline $72.5 \%$ Thyme & $19.40^{\mathrm{bc}}$ & $0.65^{\mathrm{b}}$ & $18.00^{\mathrm{de}}$ & $16.73^{\mathrm{fg}}$ & $115.83^{\mathrm{d}}$ & $23.27^{\mathrm{d}}$ & $0.83^{\mathrm{c}}$ & $18.60^{\mathrm{e}}$ & $17.23^{\text {ef }}$ & $116.00^{\mathrm{f}}$ \\
\hline $850 \%$ VOO+1\%Thyme & $17.53^{\mathrm{a}}$ & $0.62^{\mathrm{b}}$ & $19.07^{\mathrm{cd}}$ & $17.63^{\text {def }}$ & $105.00^{\mathrm{h}}$ & $27.27^{\mathrm{gh}}$ & $0.80^{\mathrm{c}}$ & $17.53^{\mathrm{ef}}$ & $18.00^{\mathrm{e}}$ & $129.50^{\text {cdef }}$ \\
\hline $950 \%$ VOO+2.5\% Thyme & $27.00^{\mathrm{h}}$ & $0.86^{\mathrm{ef}}$ & $15.60^{\mathrm{g}}$ & $17.00^{\text {ef }}$ & $103.77^{\mathrm{h}}$ & $26.77^{\mathrm{fg}}$ & $0.85^{\text {cde }}$ & $14.67^{\mathrm{g}}$ & $14.60^{\mathrm{g}}$ & $139.00^{\text {bcdef }}$ \\
\hline $10100 \%$ VOO+1\%Thyme & $23.47^{\mathrm{f}}$ & $0.82^{\mathrm{de}}$ & $11.63^{\mathrm{i}}$ & $10.50^{\mathrm{j}}$ & $112.53^{\mathrm{e}}$ & $21.53^{\mathrm{c}}$ & $0.70^{\mathrm{b}}$ & $21.00^{\mathrm{cd}}$ & $20.00^{\mathrm{d}}$ & $133.00^{\text {cdef }}$ \\
\hline $11100 \%$ VOO $+2.5 \%$ Thyme & $24.87^{\mathrm{g}}$ & $0.84^{\text {def }}$ & $16.73^{\mathrm{fg}}$ & $15.63^{\mathrm{gh}}$ & $110.57^{\mathrm{fg}}$ & $18.70^{\mathrm{ab}}$ & $0.61^{\mathrm{a}}$ & $22.00^{\mathrm{c}}$ & $19.53^{\mathrm{d}}$ & $144.67^{\text {bcdef }}$ \\
\hline $1250 \%$ (EVOO) + 1\%Thyme & $23.47^{\mathrm{f}}$ & $0.80^{\mathrm{d}}$ & $19.60^{\mathrm{bc}}$ & $18.00^{\text {cde }}$ & $121.00^{\mathrm{c}}$ & $30.87^{j}$ & $0.99^{\mathrm{f}}$ & $24.60^{\mathrm{b}}$ & $23.52^{\mathrm{bc}}$ & $122.00^{\mathrm{ef}}$ \\
\hline $1350 \%$ (EVOO) + 2.5\% Thyme & $20.00^{\mathrm{bc}}$ & $0.63^{\mathrm{b}}$ & $21.53^{\mathrm{a}}$ & $19.93^{\mathrm{b}}$ & $120.63^{\mathrm{c}}$ & $30.10^{\mathrm{j}}$ & $0.90^{\mathrm{de}}$ & $17.57^{\text {ef }}$ & $16.60^{\mathrm{f}}$ & $167.33^{\mathrm{ab}}$ \\
\hline 14 100\% (EVOO) + 1\% Thyme & $18.90^{\mathrm{b}}$ & $0.75^{\mathrm{c}}$ & $15.77^{\mathrm{g}}$ & $14.60^{\mathrm{hi}}$ & $104.37^{\mathrm{h}}$ & $29.30^{\mathrm{ij}}$ & $1.02^{\mathrm{f}}$ & $16.60^{\mathrm{f}}$ & $17.57^{\mathrm{ef}}$ & $131.67^{\text {cdef }}$ \\
\hline $15100 \%($ EVOO $)+2.5 \%$ Thyme & $21.63^{\mathrm{de}}$ & $0.72^{\mathrm{c}}$ & $17.60^{\mathrm{ef}}$ & $15.66^{\mathrm{gh}}$ & $122.77^{\mathrm{b}}$ & $17.80^{\mathrm{a}}$ & $0.63^{\mathrm{a}}$ & $20.70^{\mathrm{d}}$ & $20.63^{\mathrm{d}}$ & $124.67^{\mathrm{def}}$ \\
\hline
\end{tabular}

* Each value in a column followed by the same letter are not significantly different at $(p \leq 0.05)$.

** ALT: Alanine aminotransferase AST: Aspartate aminotransferase ALP: Alkaline phosphatase

Creat: Creatinine

Table (9). Effect of feeding on olive oil and thyme diet on hormones of female rats during experimental stages

\begin{tabular}{|c|c|c|c|c|c|c|c|c|}
\hline \multirow[b]{2}{*}{ Groups } & \multicolumn{2}{|c|}{ Female before mating } & \multicolumn{3}{|c|}{ Pregnant rats } & \multicolumn{3}{|c|}{ Lactating rats } \\
\hline & $\mathbf{E}_{2}(\mathrm{pg} / \mathrm{ml})$ & $\begin{array}{l}\text { Progesterone } \\
(\mathrm{ng} / \mathrm{ml})\end{array}$ & $\mathbf{E}_{2}(\mathrm{pg} / \mathrm{ml})$ & $\begin{array}{l}\text { Progesterone } \\
(\mathrm{ng} / \mathrm{ml})\end{array}$ & $\begin{array}{l}\text { Prolactin } \\
(\mathrm{ng} / \mathrm{ml})\end{array}$ & $\mathbf{E}_{2}(\mathrm{pg} / \mathrm{ml})$ & $\begin{array}{l}\text { Progesterone } \\
(\mathrm{ng} / \mathrm{ml})\end{array}$ & $\begin{array}{l}\text { Prolactin } \\
(\mathrm{ng} / \mathrm{ml})\end{array}$ \\
\hline 1 control & $40.00^{\mathrm{fg}}$ & $62.33^{\mathrm{a}}$ & $37.80^{\mathrm{fg}}$ & $39.60^{\mathrm{h}}$ & $39.00^{e}$ & $38.87^{\mathrm{jk}}$ & $50.47^{\mathrm{b}}$ & $27.13^{\mathrm{e}}$ \\
\hline $250 \%$ Virgin Olive Oil (VOO) & $65.00^{\mathrm{c}}$ & $56.67^{\mathrm{b}}$ & $36.50^{\mathrm{g}}$ & $39.53^{\mathrm{h}}$ & $29.57^{1}$ & $70.37^{b}$ & $55.63^{\mathrm{a}}$ & $30.97^{\mathrm{bc}}$ \\
\hline 3 100\% Virgin Olive Oil (VOO) & $73.00^{\mathrm{b}}$ & $61.00^{\mathrm{a}}$ & $38.80^{\mathrm{def}}$ & $41.03^{\mathrm{g}}$ & $30.60^{\mathrm{k}}$ & $55.33^{\mathrm{fg}}$ & $49.03^{c}$ & $26.27^{\text {fgh }}$ \\
\hline $450 \%$ Extra Virgin Olive Oil (EVOO) & $56.00^{\mathrm{d}}$ & $47.66^{\mathrm{de}}$ & $36.83^{\mathrm{g}}$ & $42.40^{\mathrm{e}}$ & $40.50^{\mathrm{d}}$ & $50.50^{\mathrm{h}}$ & $42.80^{\mathrm{f}}$ & $29.03^{\mathrm{d}}$ \\
\hline $5 \quad 100 \%$ Extra Virgin Olive Oil (EVOO) & $81.33^{\mathrm{a}}$ & $39.33^{\mathrm{g}}$ & $39.60^{\text {cde }}$ & $48.27^{\mathrm{b}}$ & $36.57^{\mathrm{f}}$ & $59.33^{\text {cd }}$ & $37.03^{\mathrm{i}}$ & $26.50^{\text {ef }}$ \\
\hline $61 \%$ Thyme & $63.33^{\mathrm{c}}$ & $49.32^{\mathrm{d}}$ & $43.00^{\mathrm{b}}$ & $48.57^{\mathrm{b}}$ & $44.60^{\mathrm{b}}$ & $64.67^{\mathrm{c}}$ & $42.40^{\mathrm{f}}$ & $28.60^{\mathrm{d}}$ \\
\hline 7 2.5\%Thyme & $65.00^{\mathrm{c}}$ & $45.00^{\mathrm{ef}}$ & $37.50^{\mathrm{fg}}$ & $40.00^{\mathrm{h}}$ & $28.00^{\mathrm{m}}$ & $62.00^{\mathrm{cd}}$ & $41.23^{\mathrm{g}}$ & $25.53^{\mathrm{h}}$ \\
\hline $850 \%$ VOO $+1 \%$ Thyme & $44.00^{\text {ef }}$ & $40.33^{\mathrm{g}}$ & $37.57^{\mathrm{fg}}$ & $45.60^{\mathrm{c}}$ & $35.15^{\mathrm{g}}$ & $40.83^{\mathrm{ij}}$ & $36.40^{\mathrm{i}}$ & $24.57^{\mathrm{i}}$ \\
\hline $950 \%$ VOO $+2.5 \%$ Thyme & $55.32^{\mathrm{d}}$ & $52.34^{\mathrm{c}}$ & $43.33^{\mathrm{b}}$ & $50.00^{\mathrm{a}}$ & $50.00^{\mathrm{a}}$ & $53.33^{\mathrm{gh}}$ & $47.50^{\mathrm{d}}$ & $33.36^{\mathrm{a}}$ \\
\hline $10100 \%$ VOO $+1 \%$ Thyme & $40.10^{\text {ef }}$ & $48.00^{\text {de }}$ & $46.00^{\mathrm{a}}$ & $41.50^{\mathrm{fg}}$ & $42.37^{\mathrm{c}}$ & $43.30^{\mathrm{i}}$ & $36.50^{\mathrm{i}}$ & $26.50^{\text {ef }}$ \\
\hline $11100 \%$ VOO $+2.5 \%$ Thyme & $47.33^{\mathrm{e}}$ & $39.00^{\mathrm{g}}$ & $38.53^{\text {ef }}$ & $42.23^{\text {ef }}$ & $38.60^{\mathrm{e}}$ & $43.60^{\mathrm{i}}$ & $45.50^{\mathrm{e}}$ & $28.47^{\mathrm{d}}$ \\
\hline $1250 \%($ EVOO $)+1 \%$ Thyme & $72.66^{\mathrm{b}}$ & $57.66^{\mathrm{b}}$ & $40.63^{\mathrm{c}}$ & $37.57^{\mathrm{i}}$ & $28.97^{1}$ & $57.33^{\text {ef }}$ & $38.50^{\mathrm{h}}$ & $30.26^{\mathrm{c}}$ \\
\hline $1350 \%$ (EVOO) $+2.5 \%$ Thyme & $65.00^{\mathrm{c}}$ & $43.67^{f}$ & $39.87^{\mathrm{cd}}$ & $43.43^{\mathrm{d}}$ & $32.30^{\mathrm{i}}$ & $63.33^{\mathrm{c}}$ & $50.0^{\mathrm{b}}$ & $25.70^{\mathrm{gh}}$ \\
\hline 14 100\% (EVOO) + 1\% Thyme & $55.33^{\mathrm{d}}$ & $49.00^{\mathrm{d}}$ & $36.57^{\mathrm{g}}$ & $40.10^{\mathrm{h}}$ & $31.30^{\mathrm{j}}$ & $55.67^{\mathrm{efg}}$ & $44.97^{\mathrm{e}}$ & $26.43^{\mathrm{efg}}$ \\
\hline $15100 \%$ (EVOO) $+2.5 \%$ Thyme & $76.66^{\mathrm{b}}$ & $52.67^{\mathrm{c}}$ & $36.61^{\mathrm{g}}$ & $45.03^{\mathrm{c}}$ & $34.00^{\mathrm{h}}$ & $75.32^{\mathrm{a}}$ & $48.93^{\mathrm{c}}$ & $31.33^{\mathrm{b}}$ \\
\hline
\end{tabular}

* Each value in a column followed by the same letter is not significantly different at $\mathrm{p} \leq 0.05$. 


\section{References}

[1] Encinias, HB; Lardy, GP; Eninias, AM and Baver, ML (2004). "High linoleic acid safflower seed supplementation for gestating ewes: Effects on ewe performance, lamb survival and brown fat stores.Journal of Animal Science, 82: 3654-3661.

[2] Trichopoulou A and Dilis V. (2007). Olive oil and longevity. Mol. Nutr. Food Res; 51: 1275 - 1278.

[3] Covas, M.I. (2007). Olive oil and cardiovascular system. Pharmacol. Res., 55; 175-186.

[4] Verbance, D. (2004). Nutrition habits in pregnant women and early childhood as a tool for obesity prerention. Paediatria Croatica 48: 41-5.

[5] Baird, DT; James, VHT; Serio, $M$ and Giusti, G (1976). Ovarian steroid secretion and metabolism in women. In: the endocrine function of the human ovary. Academic press, New York, pp: 125-133.

[6] Faber, A; Bouvy, ML; Loskamp, LS; Vande Berg, PB; Egberts, TC; de Tong- Van den Berg, LT (2005). Dramatic change in prescribing of hormone replacement therapy in the Netherland after publication of the Million women study: a following up study. Br. J. Clin. Pharmacol 60 (6): 641 - 647.

[7] Santiago-Mora, R; Casado-Diaz, A; De Castro, MD and Quesada-Gómez, JM (2011).Oleuropein enhances osteoblostogensis and inhibits adipogenses: the effect on differentiation in stem cells drived from bone marrow. Osteoporos. Int. 22 (2): 675 - 684.

[8] Rowe S, Alexander N, Almeida NG, Black R, Burns R, Bush L, Crawford P, Keim N, Kris-Etherton P and Weaver C. (2011). Translating the Dietary guidelines for Americans 2010 to bring about real behavior change. J. Am. Diet Assoc. 111 (1): 28-39.

[9] Buckland G; Travier N; Agudo A; Fonsecs-Nunes A; Navarro C; Lagiou P; Demetriou C; Amiano P; Dorronsoro M; Chirlaque M-D; Huerta J-M; Molina E; Maria-José SP; Ardanaz E; Conchi M-I; Quirós JR; Naska A; Trichopoulos D Giurdanella MC; Tumino R; Agnoli C; Grioni S; Panico S; Mattiello A; Masala G; Sacerdote C; Polidoro S; Palli D; Trichopolou A; and Gonzá AC (2012). Olive oil intake and breast cancer risk in the Mediterranean countries of the European Prospective Investigation into Cancer and Nutrition study. Int. J. Cancer: 131, 2465-2469.

[10] Chetty, N., Regene, C.K.; Harris, M.A.T; Waneence, C.D.; Dovesey, M.A.T. Dagne Hill, M.A.T.; Chetty, S.; Yarrapragada, R. and Jain. S. (1999): Dietary supplematation with olive oil influence iron concentration in rat. Nutr. Res. 19: 1665-1670.

[11] Zarachi, M.A.K. and Babaci, A. (2006): An investigation of thyme effect on Hiliocobacterpylosi. Middle. East J. of Sci. Res. 1 (1): 54-57.

[12] Reeves, P.G.; Nielsen, F.H. and Fahey, G.C. (1993). “AIN-93 purified diets for laboratory rodents: final report of the American Institute of Nutrition Ad HOC writing Committee on the reformulation of the AIN-76 a rodent diet." J. Nutr., 123(12): 1939- 1951.

[13] Drury, R.A. and Wallington, E.A. (1980). Carton's. Histological Technique. $5^{\text {th }}$ ed Oxford Univ.

[14] Allain, C.Z.; Poon, Z.S. and Chen, C.S. (1974): Enzymatic determination of total serum cholesterol. Clin Chem. 20: 470475 .

[15] Fossati, P. and Principle, L. (1982). Enzymatic colorimetric method to determination triglyceriods. Clin. Chem. 28: 2077.

[16] Burstein, M. (1970): HDL cholesterol determination after separation high density lipoprotein. Lipid. Res. 11: 583.

[17] Essam El-Din, Maha, M. (2012). The protective effect of Turnip leaves against oxidative stress induced by high cholesterol diet in adult rats. World Applied Science Journal 20 (1): $154-163$.

[18] Abbott, R.D.; Wilson, P.W.; Kannel, W.B. and Castelli, W.P. (1988). High density lipoprotein cholesterol, total cholesterol screening, and myocardial infarction. The Framingham Study. Arteriosclerosis, 8, 207-211.

[19] Patton, CJ and Crouch, SR (1977). Enzymatic colorimetric method to determination urea in serum. Anal. Chem. 49: 464.

[20] Bohmer, H.B.U.M. (1971): Micro determination of creatinine Clin. Chem. Acta 32: 81-85.

[21] Reitman, S and Frankel, S (1957). A colorimetric method for the determination of serum glutamic oxaloactic and glucanic pyruvic transaminase. Am. J. Clin. Path. 28: 56.

[22] Belfield, A and Golobkrg, DM (1971): Human serum glucose6- phosphate activity conformation of its presence and lack of diagnostic value. Enzyme 12: 561.

[23] A.O.A.C. (2000). Official Methods of Analysis of the Association of the Analytical Chemists. $17^{\text {th }}$ ed published by the Association of Official Analytical Chemists. Po Box 540. Benjamin Franklin Station Washington DC. 20044.

[24] Arjmand, B.H.; Alekel, L.; Hollis, B.W.; Amin, D.; Sapuntialcis, A.S., Guo, P and Pukereja, S.C. (1996): Dietary soybean prevents bone loss in an ovariectomyed not model of osteoporosis. J. Nut. 126: 161-167.

[25] Blum; SC; Heaton, SN; Bowma, BM; Hegsted, M and Millei, SC (2003). Dietary soybean maintains some indices of bone mineral density and bone formation in aged overiectomized rats. J. Nutr. 1313: 1244-1249.

[26] Tietz, NW (1995). Clinical guide to laboratory test. 3 edition, W. B. Saunders, Co., Philadelphia, pp: 578-580.

[27] Siiteri, PK; Murai, JT; Hammond, GL; Nisker, JA; Raymoure, WJ and Kuhn, RW (1982). The serum transport of steroid hormones. Rec. Prog. Horm. Res., 38: 457-510.

[28] Kass L, Durando M, Ramos JG, Varayoud J, Powell CE, Luque EH andMuñoz-de-Toro M (2004). Association of increased estrogen receptor beta2 expression with parityinduced alterations in the rat mammary gland. J Steroid BiochemMolBiol 91 (1-2):29-39.

[29] Church, MW K-L; Catherine, J; Pellizzon, MA and Holmes, PA (1998). Prenatal Cocaine, Alcohol and Undernutrition Differentially Alter Mineral and Protein Content in Fetal rats. Pharmacology Biochemistry and Behavior, 59(3): 577 - 584. 
[30] Snedecor, GW and Cochran WG (1989). Statistical methods. The Lowa State University Press. Ames, Lowe.

[31] González-Santiago M; Martín-Bautista E; Carrero JJ; Fonollá J; Baró L; Bartolomé MV; Gil-Loyzaga P. and López-Huertas E. (2006). One-month administration of hydroxytyrosol, a phenolic antioxidant present in olive oil, to hyperlipemic rabbits improves blood lipid profile, antioxidant status and reduces atherosclerosis development. Atherosclerosis 188, 3542.

[32] Kotogionni, MD, Melistas, L; Yanakoulia, M.Malagaris I, Panagiotakos DB and Yiannakouris N(2009). Association between dietary patterns and indices of bone mass in a sample of Mediterranean women. Nutr. 25 (2): 165 - 171.

[33] Trichopoulou A; Georgiou E; Bassiakos Y; Lipworth L; Lagiou P; Proukakis C and Trichopoulos D (1997). Energy intake and monounsaturated fat in relation to bone mineral density among women and men in Greece. Prev. Med. 26: $395-400$.

[34] Puel $\mathrm{C}^{1}$, Mathey J, Agalias A, Kati-Coulibaly S, Mardon J, Obled C, Davicco MJ, Lebecque P, Horcajada MN, Skaltsounis AL and Coxam V(2006). Dose-response study of effect of oleuropein, an olive oil polyphenol, in an ovariectomy/inflammation experimental model of bone loss in the rat. Clin. Nutr. 25 (5): $859-868$.

[35] Hagiwara, K; Goto, T; Araki, M; Miyazaki, H and Hagiwara, $\mathrm{H}$ (2011). Olive polyphenol hydroxytyrosol prevents bone loss. Euro. J. Pharmacol., 662: $78-84$.

[36] Al-Amoudi and Araki (2013). Evaluation of vegetable and fish oils diets for the amelioration of diabetes side effects. Journal of Diabetes \& Metabolic Disorders 12:13.
[37] Gorinstein, S; Leontowicz, HS;Leontowicz, M; Ciz, M; Krzeminski, R; Gralak, M.; Czerwinski, J; Jastrzebski, Z; Trakhtenberg, S; Grigelme-Mignel, N; Soliva -Fortung, R and Marten-Belloso, O (2002): Olive oil improve lipid metabolism and increase antioxidant potential in rats fed diet containing cholesterol. J. Agric. Food Chem. 50: 6102-6108.

[38] Aguilera CM; Ramirez-Tortosa MC; Mesa MD; RamirezTortosa CL and Gil A (2002). Sunflower, virgin-olive and fish oils differentially affect the progression of aortic lesions in rabbits with experimental atherosclerosis. Atherosclerosis, 162: $335-44$.

[39] Egba, SI; Udom, ID and Oknkwo CO (2014).Comparative Effect of Oral Administration of Some Dietary Lipids on Fertility Hormones of Female Wistar Albino Rats. Global Journal of Biotechnology and Biochemistry, 9 (1): 24-29.

[40] Michael J (2007). Neurology and General medicine: expert consults: online and print Edinburgh Churchill Living Stone.

[41] Cerri, RLA, Rutighiano, HM; Chebel RC and Santos, JEP (2009). Period of dominance of the ovulatory follicle influences embryo quality in lactating dairy cows. Reproduction, 137: 813-823.

[42] Reed, MJ; Cheng, RW; Simmonds, M; Richmond, W and James, VH (1987). Dietary lipids: an additional regulator of plasma levels of sex hormones binding globulin. J. Clin. Endocrinology, Metab. 64(5): 1083. 